\title{
PELATIHAN PENERAPAN PUEBI UNTUK GURU DAN PENGAWAS MADRASAH DI KABUPATEN MAGELANG
}

\author{
Winasti Rahma Diani ${ }^{1}$, Liana Shinta Dewi \\ ${ }^{1}$ Universitas Tidar \\ ${ }^{2}$ Universitas Tidar \\ winastirahma@untidar.ac.id ${ }^{1}$, lianashinta@untidar.ac.id ${ }^{2}$
}

Submitted : 10 Oktober 2021 Accepted: 10 Desember 2021 Publis hed : 31 Desember 2021

\begin{abstract}
Abstrak
Bahasa Indonesia adalah bahasa resmi yang digunakan sebagai bahasa pengantar pendidikan. Melihat pentingnya kedudukan bahasa Indonesia di dunia pendidikan, para guru dan pengawas madrasah dituntut memiliki keterampilan bahasa Indonesia yang baik. Untuk meningkatkan keterampilan tersebut, pelatihan penerapan Pedoman Umum Ejaan Bahasa Indonesia (PUEBI) dilaksanakan dalam tiga sesi, yaitu tes awal, presentasidan diskusi, serta tes akhir. Tes awal ditujukan untuk mengukur tingkat pemahaman awal peserta. Materi soal mencakup (1) huruf kapital, (2) penggunaan tanda baca, (3) penulisan singkatan dan gelar, (4) penulisan istilah asing, (5) penulisan kata baku dan serapan. Dari hasil tes awal, diketahui tingkat pemahaman peserta terhadap PUEBI belum cukup baik, terutama dalam penulisan kata serapan dan gelar. Setelah melalui tes awal, peserta mendapat materi penerapan PUEBI melalui presentasi dan diskusi. Kemudian, keterampilan peserta dalam penerapan PUEBI kembali diuji pada tes akhir. Hasilnya, nilai tes akhir menunjukkan adanya peningkatan, yaitu dari rata-rata 53,7 menjadi 75,45.
\end{abstract}

Kata Kunci: huruf kapital, penulisan kata, PUEBI, singkatan, tanda baca 


\section{PENDAHULUAN}

Bahasa Indonesia adalah bahasa resmi negara Indonesia. Hal tersebut terdapat dalam Undang-Undang 1945 Pasal 36 yang menyatakan bahwa bahasa negara ialah bahasa Indonesia. Sebagai bahasa resmi negara, bahasa Indonesia berfungsi sebagai bahasa resmi kenegaraan, pengantar pendidikan, komunikasi tingkat nasional, pengembangan kebudayaan nasional, transaksi dan dokumentasi niaga, serta sarana pengembangan dan pemanfaatan ilmu pengetahuan, teknologi, seni, dan bahasa media massa (UU Nomor 24 Tahun 2009 Pasal 25).

Peraturan tersebut menegaskan bahwa sebagai bahasa resmi negara, bahasa Indonesia wajib digunakan sebagai bahasa pengantar pendidikan untuk semua tingkatan dari tingkat SD, SMP, SMA/SMK, hingga tingkat perguruan tinggi. Berdasarkan hal tersebut, para guru dan pengawas madrasah dituntut untuk memiliki keterampilan bahasa Indonesia yang baik secara lisan dan tulisan. Bagi guru, keterampilan bahasa Indonesia yang baik secara lisan bermanfaat untuk menyampaikan materi pembelajaran serta berkomunikasi dengan siswa dan orang tua/wali. Kemudian, bagi pengawas madrasah, keterampilan menggunakan bahasa Indonesia secara lisan yang baik dibutuhkan agar dapat menyampaikan informasi dengan baik pula. Sementara itu, keterampilan bahasa Indonesia secara tertulis bermanfaat untuk menyusun materi ajar, membuat laporan, menulis karya ilmiah, dan lainlain.

Jadi, keterampilan berbahasa Indonesia secara lisan maupun tulisan perlu dikuasai dengan baik oleh guru dan pengawas sekolah yang memiliki peranan penting dalam pendidikan. Untuk mendukung peningkatan keterampilan para guru dan pengawas madrasah dalam berbahasa Indonesia, perlu diadakan pelatihan-pelatihan dalam bidang kebahasaan. Salah satunya adalah pelatihan penerapan Pedoman Umum Ejaan Bahasa Indonesia (PUEBI) yang dapat menunjang peningkatan keterampilan para guru dan pengawas madrasah dalam menulis dan meningkatkan kualitas tulisannya.

Secara umum, materi pelatihan penerapan PUEBI mencakup pemakaian huruf, penulisan kata, pemakaian tanda baca, dan penulisan unsur serapan. Materi-materi tersebut akan disampaikan dalam pelatihan yang akan 
diselenggarkan untuk para guru dan pengawas madrasah di wilayah Kabupaten Magelang. Dengan mengikuti pelatihan, para guru dan pengawas madrasah diharapkan mampu memahami bagaimana menerapkan aturan-aturan PUEBI dengan baik dalam tulisannya, sehingga tulisan yang dihasilkan dapat dibaca dan dipahami dengan mudah oleh para pembaca.

$$
\text { Menurut Karyati (2016), }
$$
sosialisasi terkait aturan perkembangan ejaan perlu dilakukan agar masyarakat pengguna bahasa Indonesia dapat mengetahui aturan yang benar.

\section{TINJAUAN PUSTAKA}

Pedoman Umum Ejaan Bahasa Indonesia (PUEBI) pertama kali diterbitkan pada tahun 2015 oleh Badan Pengembangan dan Pembinaan Bahasa, Kementerian Pendidikan dan Kebudayaan, untuk menggantikan Ejaan yang Disempurnakan (EYD). PUEBI ditujukan sebagai rujukan yang dapat dijadikan pedoman dan acuan berbagai kalangan pengguna bahasa Indonesia, terutama dalam pemakaian ragam bahasa tulis secara baik dan benar (Badan Pengembangan dan Pembinaan Bahasa, 2015).

Penetapan PUEBI juga telah diperkuat dengan dikeluarkannya
Keputusan Kepala Badan

Pengembangan dan Pembinaan Bahasa

Kementerian Pendidikan, Kebudayaan,

Riset, dan Teknologi Republik Indonesia

Nomor 0321/I/BS.00.00/2021 tentang

Pedoman Umum Ejaan Bahasa

Indonesia. Dalam keputusan tersebut, ditetapkan sebagai pedoman bahasa Indonesia yang baik dan benar. Hal tersebut ditetapkan bagi pemerintah, swasta, dan masyarakat (Salinan RKKB PUEBI 1, 2021.

Secara garis besar, materi PUEBI dapat dibagi menjadi tiga bagian, yaitu pemakaian huruf, penulisan kata, dan pemakaian tanda baca. Pertama, pedoman pemakaian huruf ditujukan untuk menetahui bagaimana penulisan abjad, vokal, konsonan, diftong, dan gabungan konsonan dalam bahasa Indonesia. Selain itu, pada bagian ini juga dibahas mengenai penggunaan huruf kapital, miring, dan tebal. Penulisan huruf berkaitan dengan ejaan. Menurut (Fidalgo et al., 2018), pengejaan adalah proses untuk mengubah apa yang ada dalam pikiran (semantik) ke dalam tulisan dan proses transkripsi untuk merekam bahasa tulis. Itulah sebabnya, perihal ejaan perlu memiliki pedoman yang dapat menjadi standar bagi para penggunanya. 
Lebih lanjut lagi, Alex dan Achmad (2010) menyampaikan bahwa ejaan adalah peraturan yang melambangkan bunyi ujaran, pemisahan dan penggabungan kata, penulisan kata, huruf, dan tanda baca. Selain itu, menurut Wijayanti (2013), ejaan merupakan kaidah cara menggambarkan atau melambangkan bunyi-bunyi ujaran, seperti kata, kalimat, dan sebagainya serta bagaimana hubungan antara lambang-lambang tersebut dalam suatu bahasa.

Kedua, pada bagian penulisan kata dibahas mengenai 1) kata dasar, 2) kata berimbuhan, 3) bentuk ulang, 4) gabungan kata, 5) pemenggalan kata, 6) kata depan, 7) partikel, 8) singkatan dan akronim, 9) angka dan bilangan, 10) kata ganti, dan 11) kata sandang. Pembahasan pada bagian tersebut berkaitan dengan pembentukan kata yang termasuk dalam kajian bidang morfologi.

Istilah morfologi didefinis ika n oleh Chaer (2008) sebagai ilmu mengenai bentuk. Di dalam linguistik, kajian morfologi adalah bentuk-bentuk kata dan proses pembentukan kata.

Ketiga, pada bagian pemakaian tanda baca dijelaskan mengenai pemakaian lima belas tanda baca, yaitu 1) tanda titik, 2) tanda koma, 3) tanda titik koma, 4) tanda titik dua, 5) tanda hubung, 6) tanda pisah, 7) tanda tanya, 8) tanda seru, 9) tanda elipsis, 10) tanda petik, 11) tanda petik tunggal, 12) tanda kurung, 13) tanda kurung siku, 14) tanda garis miring, dan 15) tanda penyingkat atau apostrof. Tanda baca dibaratkan seperti sinyal yang digunakan untuk mengarahkan pembaca saat menelusuri teks, sehingga dapat lebih mudah memahami isi teks (Suliman et al., 2019).

Kegiatan pelatihan penerapan PUEBI pernah dilaksanakan oleh (Muzaki \& Chadis, 2019) untuk guruguru sekolah dasar. Pelatihan tersebut ditujukan untuk memberikan pengetahuan mengenai PUEBI. Berbeda dengan kegiatan tersebut, penulis memilih melaksanakan pelatihan penerapan PUEBI tidak hanya ditujukan untuk guru, tetapi juga untuk para pengawas madrasah.

$$
\text { Menurut Utami }
$$

pengajaran tata bahasa dapat dilakukan dengan menanamkan kebiasaan menerapkan aturan-aturan bahasa. Proses tersebut termasuk dalam pemerolehan bahasa. Oleh karena itu, pengajaran tata bahasa memerlukan repetisi, penggunaan bentuk yang 
bermakna, dan latihan penggunaan tata bahasa sesuai konteksnya.

\section{METODE PENGABDIAN}

Metode yang diterapkan dalam program PKM ini adalah dengan tes awal, presentasi \& diskusi, serta tes akhir. Dengan menggunakan metode tersebut, diharapkan dapat memicu interaksi aktif antara tim pelaksana dan para peserta pelatihan. Semua tahapan kegiatan dilakukan secara daring karena aturan PPKM (Pemberlakuan Pembatasan Kegiatan Masyarakat) masih berlaku. Ada pun rincian aktivitas pelatihan yang dilaksanakan adalah sebagai berikut.

\subsection{Tes Awal}

Sebelum masuk pembahasan materi pelatihan, peserta diminta untuk mengikuti tes awal (pretest) untuk mengetahui kondisi awal atau sejauh mana peserta memahami PUEBI. Tim PKM menggunakan media Google Form untuk tes awal. Google Form dipilih sebagai media untuk tes awal karena para peserta sudah cukup familiar dan pernah menggunakannya.

Jenis soal yang diberikan pada tes awal adalah pilihan ganda. Dalam tes tersebut, terdapat lima soal pilihan ganda. Peserta diminta memilih jawaban yang sesuai dengan aturan PUEBI.

Untuk dapat menjawab dengan tepat, peserta harus mencermati pilihan jawaban dengan baik.

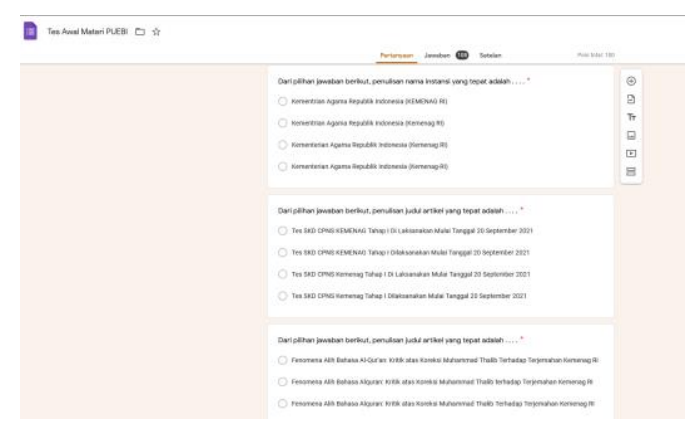

Gambar 1. Tampilan Tes Awal Melalui Google Form

\subsection{Presentasi dan Diskusi}

Setelah peserta mengikuti kuis, tim PKM mempresentasikan materi tentang aturan-aturan PUEBI dan bagaimana penerapannya. Dalam presentasi, tim PKM memberikan contoh-contoh penerapan PUEBI yang berkaitan dengan pekerjaan peserta di ranah pendidikan dan lingkungan Kementerian Agama. Selanjutnya, kegiatan dilanjutkan dengan sesi diskusi dan tanya jawab. Dalam sesi ini, peserta dapat menyampaikan kesulitan-kesulitan yang dihadapi oleh mereka dalam menerapkan PUEBI. 


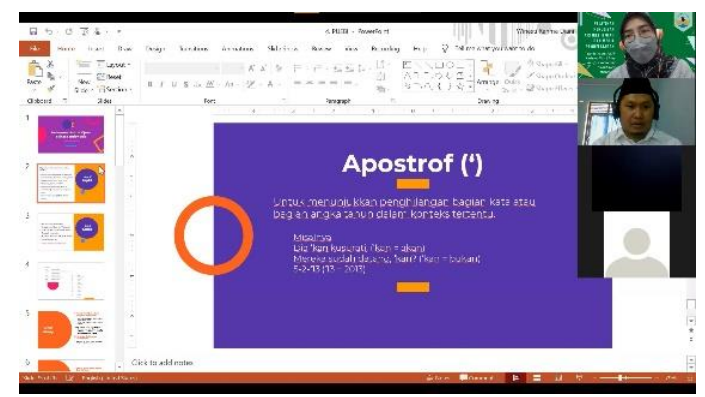

Gambar 2. Sesi Presentasi Melalui Zoom

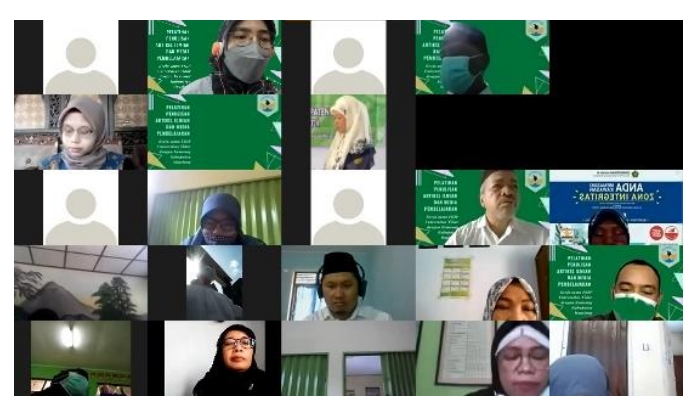

Gambar 3. Guru dan Pengawas Madrasah Peserta Pelatihan

\subsection{Tes Akhir}

Terakhir, para peserta pelatihan diminta untuk mengikuti tes akhir. Tujuan diadakannya tes ini adalah untuk mengukur perkembangan pemahaman peserta setelah mengikuti pelatihan. Sama seperti tes awal, tes akhir pun berupa lima soal pilihan ganda dan diberikan melalui media Google Form.

\section{HASIL DAN PEMBAHASAN}

Hasil dan pembahasan dari kegiatan pelatihan penerapan PUEBI untuk guru dan pengawas madrasah di Kabupaten Magelang akan dibahas dalam tiga subbab. Pada subbab pertama akan dibahas mengenai hasil dari tes awal para peserta. Kemudian, dilanjutkan dengan subbab presentasi dan diskusi. Lalu, pada subbab terakhir akan dibahas mengenai hasil tes akhir.

\subsection{Hasil Tes Awal}

Tes awal diikuti oleh semua peserta pelatihan sebelum mendapatkan materi mengenai PUEBI. Melalui kolom obrolan aplikasi telekonferensi Zoom, perwakilan tim PKM memberikan tautan Google Form. Kemudian, peserta diberi waktu sepuluh menit untuk mengerjakan tes awal.

Dalam tes tersebut, ada lima soal pilihan ganda tentang penerapan PUEBI. Peserta diminta untuk memilih jawaban yang paling tepat dan sesui dengan aturan PUEBI. Materi soal mencakup (1) huruf kapital, (2) penggunaan tanda baca, (3) penulisan singkatan dan gelar, (4) penulisan istilah asing, (5) penulisan kata baku dan serapan.

Hasil dari tes awal yang menggambarkan pemahaman para peserta mengenai PUEBI dapat dilihat pada grafik berikut.

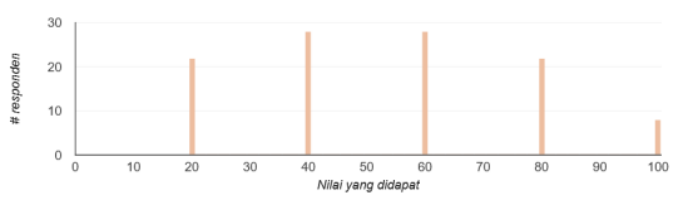

Gambar 1. Nilai Tes Awal 
Grafik tersebut memperlihatkan rentang nilai tes awal para peserta, yaitu 20-100. Rata-rata nilai tes awal hanya 53,7. Dari nilai tersebut, dapat diketahui bahwa rata-rata peserta pelatihan belum cukup memahami bagaimana menerapkan aturan PUEBI.

Dari lima soal, terdapat satu soal yang paling banyak dijawab salah oleh $65 \%$ peserta. Pada soal tersebut, terdapat contoh penulisan judul artikel ilmiah, yaitu "Fenomena Alih Bahasa Quran: Kritik atas Koreksi Muhammad Thalib terhadap Terjemahan Kemenag RI".

Berdasarkan jawaban salah yang paling banyak dipilih, diketahui bahwa para peserta tidak mengetahui penulisan 'Quran' yang baku. Sebanyak 31,5\% peserta terkecoh dengan pilihan jawaban yang menyertakan kata 'Al-qur'an', padahal bentuk tersebut bukan merupakan kata baku.

Selain itu, pertanyaan yang banyak dijawab salah oleh peserta adalah tentang penulisan gelar. Misalnya, penulisan gelar Dr. (Doktor) dan S.Pd.I (Sarjana Pendidikan Islam). Kedua gelar tersebut sengaja dicantumkan pada soal karena cukup familiar di lingkungan madrasah dan Kemenag. Namun, ternyata, $48 \%$ peserta tidak mengetahui bagaimana penulisan gelar tersebut yang sesuai dengan aturan PUEBI.

\subsection{Sesi Presentasi dan Diskusi}

Setelah semua peserta selesai mengerjakan tes awal, pemateri menyampaikan materi tentang PUEBI melalui Zoom. Materi yang diberikan merupakan ringkasan dari buku PUEBI. Selain itu, pemateri juga menambahkan dengan contoh-contoh penerapan PUEBI yang relevan dan dekat dengan lingkungan peserta, terutama di bidang pendidikan.

Kemudian, pada sesi diskusi dan tanya jawab, pemateri memberi kesempatan bertanya bagi para peserta. Beberapa pertanyaan yang disampaikan adalah perbedaan penulisan singkatan dengan akronim, penulisan nominal rupiah, penulisan huruf kapital pada pilihan jawaban pilihan ganda, dan lainlain

Setelah itu, pemateri membahas satu per satu soal tes awal yang telah dikerjakan oleh para peserta. Pemateri memberi kesempatan bagi para peserta untuk menjawab soal-soal tersebut. Beberapa peserta pun menyampaikan kesalahannya karena kurang cermat dalam memilih jawaban. Ada pula yang menyatakan bahwa pilihan jawabannya 
berdasarkan bentuk penggunaan yang sering ia lihat. Namun, sayangnya, bentuk penggunaan tersebut merupakan contoh yang salah.

Melalui sesi diskusi ini, peserta menyadari bahwa di lingkungan sekitarnya masih banyak penggunaan bahasa yang kurang sesuai dengan aturan PUEBI. Bahkan, hal tersebut masih sering dijumpai pada dokumen dan media resmi pemerintah.

\subsection{Tes Akhir}

Seperti halnya tes awal, tes akhir diberikan melalui media Google Form. Durasi pengerjaan tes pun sama, yaitu sepuluh menit. Jadi, setelah sesi diskusi berakhir, tim PKM segera membagikan tautan Google Form melalui kolom obrolan Zoom.

Berikut adalah hasil tes akhir peserta pelatihan penerapan PUEBI.

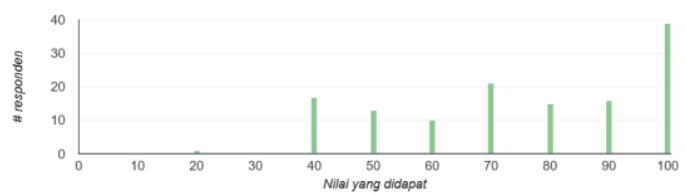

Gambar 2. Nilai Tes Akhir

Jika dibandingkan dengan gambar 1, grafik pada gambar 2 menunjukkan adanya peningkatan.

Rentang nilai tes akhir berada pada 40 100. Kemudian, nilai rata-rata tes akhir peserta meningkat menjadi 75,45 .
Hal tersebut menunjukkan adanya peningkatan pemahaman para peserta setelah mendapatkan materi tentang PUEBI. Untuk soal yang menampilkan gelar dan singkatan persentase jawaban benar mencapai 98,5\%. Padahal, di tes awal, soal serupa hanya mampu dijawab oleh $52 \%$ peserta.

\section{KESIMPULAN}

Pelatihan penerapan PUEBI dilaksanakan dalam tiga sesi, yaitu tes awal, presentasi dan diskusi, serta tes akhir. Hasil tes awal menunjukkan masih kurangnya pemahaman peserta terkait aturan PUEBI, terutama dalam penulisa $n$ kata serapan dan gelar. Kemudian, dalam sesi diskusi, peserta tidak hanya bertanya mengenai aturan PUEBI, tetapi juga memberikan contoh-contoh penggunaan bahasa yang belum baik dan benar di lingkungan sekitarnya. Kesempatan tersebut memperdalam pemahaman peserta mengenai PUEBI yang ditunjukkan pada tes akhir. Dari perbandingan nilai tes awal dan tes akhir, dapat diketahui adanya peningkatan nilai rata-rata, yaitu dari 53,7 menjadi 75,45.

\section{UCAPAN TERIMAKASIH}

Ucapan terima kasih kami sampaikan pada Fakultas Keguruan dan Ilmu 
Pendidikan Universitas Tidar yang telah mendukung kegiatan pengabdian ini, baik dari segi moral maupun material. Kemudian, terima kasih juga kami ucapkan kepada Kementerian Agama Kabupaten Magelang sebagai mitra pengabdian. Berkat bantuan dari semua pihak, kegiatan pengabdian ini dapat terlaksana dengan baik.

\section{DAFTAR PUSTAKA}

Alex, A. dan Achmad, H. P. (2010). Bahasa Indonesia untuk Perguruan Tinggi. Jakarta:

Kencana Prenada Media Group.

Chaer, Abdul. 2008. Morfologi Bahasa Indonesia Pendekatan Proses. Jakarta: Rineka Cipta.

Fidalgo, R., Olive, T., Board, E., Alves, R. A., Harris, K., \& Rijlaarsdam, G. (2018). Studies in Writing Series Editors. http://ccn. loc.gov/2017032915

Indonesia. Badan Pengembangan dan Pembinaan Bahasa. (2015). Pedoman umum ejaan bahasa Indonesia.

Karyati, Z. (2016). ANTARA EYD DAN PUEBI: SUATU ANALISIS
KOMPARATIF. In Jurnal SAP

(Vol. 1, Issue 2).

Muzaki, A., Chadis, C., \& Agustin, Y. (2019). Pengenalan Pedoman Umum Ejaan Bahasa Indonesa (PUEBI) dalam Mengembangkan Kemampuan Berbahasa Indonesia yang Baik dan Benar bagi para Guru. Jurnal PkM (Pengabdian kepada Masyarakat), 2(02), 82-86.

Salinan RKKB PUEBI 1. (2021).

Suliman, F., Ben-Ahmeida, M., \& Mahalla, S. (2019). Importance of Punctuation Marks for Writing and Reading Comprehension Skills. https://misuratau.edu.ly/journa1/arts

Utami, S. R. (2017). Pembelajaran Aspek Tata Bahasa dalam Buku Pelajaran Bahasa Indonesia. Aksis: Jurnal Pendidikan Bahasa dan Sastra Indonesia, 1(2), 189-203.

Wijayanti, dkk. (2013). Bahasa Indonesia: Penulisan dan Penyajian Karya Ilmiah. Jakarta: PT Raja Grafindo Persada. 